\title{
Evaluation of a Strategy-Oriented Method to Identify and Prioritise Knowledge Management Initiatives in SMEs
}

\author{
Juan Ignacio Igartua-López ${ }^{1}(\mathbb{D})$, Jabier Retegi-Albisua ${ }^{2}$ (D), Maria Ruiz ${ }^{3}$ (i), Maitane Mindegia ${ }^{4}$ (iD \\ ${ }^{1}$ Mechanical and Industrial Production Department Mondragon University - Faculty of Engineering (Spain) \\ ${ }^{2}$ Mondragon Unibertsitatea \& Orkestra - Basque Institute of Competitiveness (Spain) \\ ${ }^{3}$ ISE A S.Coop. (Spain) \\ ${ }^{4}$ Piarres Larzabal High School. Ciboure (Spain) \\ jigartua@mondragon.edu,jretegi@mondragon.edu,mruiz@isea.eus,maitane.mindegia@plk.eus
}

Received: July 2020

Accepted: November 2020

\begin{abstract}
:
Purpose: This article presents the process followed for the definition, application and evaluation of a strategy-oriented method for identifying and prioritising knowledge management (KM) initiatives in smallto medium-sized enterprises (SMEs).
\end{abstract}

Design/methodology/approach: To develop the method, the research team conducted a literature review of the existing business strategies and processes and models of maturity in KM. Based on this, the first version of the method is proposed. Subsequently, the method was explored through a focus group composed of regional development centres, business innovation centres and industry representatives. Then, the four-step method, called KM-EZAGUTUZ, for the identification and prioritisation of KM initiatives in SMEs was proposed. Afterwards, a field test was performed in five companies.

Findings: The conclusions obtained through the research show the validity of the method, which helps SMEs identify and prioritise KM initiatives.

Research limitations/implications: More field tests should be done to confirm the validity of the method and improve it. Furthermore, the research concludes that strategy-focused KM is a good approach for SMEs, allowing them to approach KM from a consistent and pragmatic perspective. The research also provides insights into the main difficulties faced by SMEs in implementing KM.

Practical implications: The method, which is developed and supported in a prototype tool, helps companies quickly determine and prioritise the actions for better $\mathrm{KM}$ in accordance with company strategies. In addition, the method supports a common understanding of the strategic vision of the organisation among the participants taking part in the process.

Social implications: Management practices are usually designed for medium- and large-sized companies. The significant resources required make it difficult for SMEs to benefit from the implementation of such practices. Given that SMEs account for a large share of employment in countries and that they need to manage knowledge effectively, this research helps address this important socio-economic need.

Originality/value: The method described in the article combines strategy, knowledge management and a user-friendly identification and prioritisation tool adapted to SMEs.

Keywords: knowledge management, strategic management, management tools, SMEs 


\section{To cite this article:}

Igartua-López, J.I., Retegi-Albisua, J., Ruiz, M., \& Mindegia, M. (2021). Evaluation of a Strategy-Oriented Method to Identify and Prioritise Knowledge Management Initiatives in SMEs. Journal of Industrial Engineering and Management, 14(1), 3-14. https://doi.org/10.3926/jiem.3277

\section{Introduction}

The term knowledge management (KM) emerged in the 1980s as a management area distinct from the other areas of business management (Wiig, 1997). Since then, over the past few decades, the concept of KM has been addressed from diverse perspectives (Cerchione, Esposito \& Spadaro, 2016; Gao, Chai \& Liu, 2017), including perspectives related to information management (based on the development of information and communication technologies), the management of intangible assets existing in people that are transmitted and generated through the interactions between them, the link between knowledge and the capacity for innovation, the generation of talent and the transfer of technology (Mohamed, 2019). Less attention has been paid to the necessary link between KM and the strategy implemented by companies (Zheng, Yang \& McLean, 2010).

The current article focuses on KM in small- to medium-sized enterprises (SMEs) from a strategic perspective (Samiei \& Habibi, 2020). Indeed, depending on the strategic position of a company and its weaknesses, threats, strengths, opportunities and actions taken, a firm's position with respect to KM may be different; therefore, the perspective and priorities will also be diverse. The proposed method takes as reference this strategic point of view, from which a company evaluates the key knowledge needed to achieve a better competitive advantage today and/or in the future, focusing its efforts on leveraging its position in those key elements. The kind of initiatives identified may lead to the development of new information and communication systems based on the evolution of current technology, the implementation of a talent management plan or the establishment of innovative cycles in the company, among others (Chawla \& Joshi, 2010; Clarke \& Rollo, 2001; Hutchinson \& Quintas, 2008).

In particular, taking into account that micro-enterprises and SMEs need to effectively manage knowledge (Hutchinson \& Quintas, 2008), the present article presents a proposal for a method of identifying KM initiatives that are suitable to them (with a limited dedication of time, a pragmatic approach and an orientation towards a shared vision).

\section{Literature Review}

Companies need to manage knowledge with a strategic vision (Drew, 1999). Knowledge is an important group of intangible resources that can be the source of a sustainable competitive advantage (Civi, 2000). Lee and Wong (2015) state that KM is an important means of improving the competitive position of companies.

In fact, knowledge can be the source of differentiation because of its immobility (McEvily \& Chakravarthy, 2002) and general applicability (Cerchione et al., 2016). Knowledge allows a firm to predict more accurately the nature and commercial potential of changes in the environment and the desirability of strategic and tactical actions

If the construction of the knowledge-economy paradigm is considered one of today's new challenges, the challenge for organisations then becomes the management of knowledge and the means of becoming an 'intelligent organisation' (Jackson 2001; Nonaka 1994). Although such management is influenced by the size of the company, micro-enterprises also need to manage knowledge to maintain their competitive position (Civi, 2000). These contributions are aligned with other research that has shown that the size of an organisation affects its behaviour and structure, influencing the adoption and implementation of KM (Durst \& Edvardsson, 2012).

Thus, various authors (Alvarez, Cilleruelo \& Zamanillo, 2016) have stated that the acquiring, sharing and transferring of knowledge have similar characteristics, regardless of the size of the company. However, the formalisation and storage of knowledge takes a more implicit character in the case of micro-enterprises, while 
medium-sized enterprises have a greater capacity to establish structured systems of knowledge coding and storage.

In this context, it is key for companies to become aware of their KM approaches and evaluate their management system. Lee and Wong (2015) conclude that the evaluation of KM performance has become increasingly vital because it provides direction for organisations to enhance their performance and competitiveness. The same research indicates that the measurement of $\mathrm{KM}$ remains focused on large organisations, with the inherent idea that SMEs do not need or are not ready for KM. Despite this idea, a growing number of SMEs consider KM to be vital to the growth and success of their businesses (Kurniawati, Wiratmadja, Sunaryo \& Ari Samadhi, 2019).

One of the potential methods of responding to this challenge has been exposed by Kuriakose, Satya Murty and Swaminathan (2010), who describe a series of maturity models of KM. Most of the analysed models have functional orientations (people management, technology, infrastructure, leadership, processes) performing a partial evaluation of a company without using an integrative strategic approach. The proposed approach in this article, on the other hand, emphasises the role of $\mathrm{KM}$ in the fulfilment of strategy, hence seeking a comprehensive vision of KM.

Based on the above, the authors consider that there is a growing need for academic institutions, research organisations, intermediary agents and consulting firms to develop practical research approaches to help SMEs manage their KM needs.

For developing the method, the research team conducted a review of existing business strategies (Lee, Lim \& Tan, 1999; Leitner \& Güldenberg, 2010; White, 1986), KM processes (Costa \& Monteiro, 2016; Henao-Calad, Rivera Montoya \& Uribe Ochoa, 2017; Wee \& Chua, 2013) and some maturity models in KM (Kuriakose et al., 2010).

\section{KM-EZAGUTUZ Method Pillars}

As shown in Figure 1, the method rests on three basic pillars: (1) a standardised catalogue of potential business strategies; (2) the phases of the KM process (ICSPAD); and (3) a self-assessment questionnaire with a maturity model approach. At the crossroads between the prioritised strategies and each of the phases of the KM process is the opportunity for an analysis of the maturity of $\mathrm{KM}$ and, as a consequence, the identification of opportunities for improvement. This opportunity analysis is carried out through a set of questions adapted to each strategy and each phase of the proposed KM process (ICSPAD cycle).

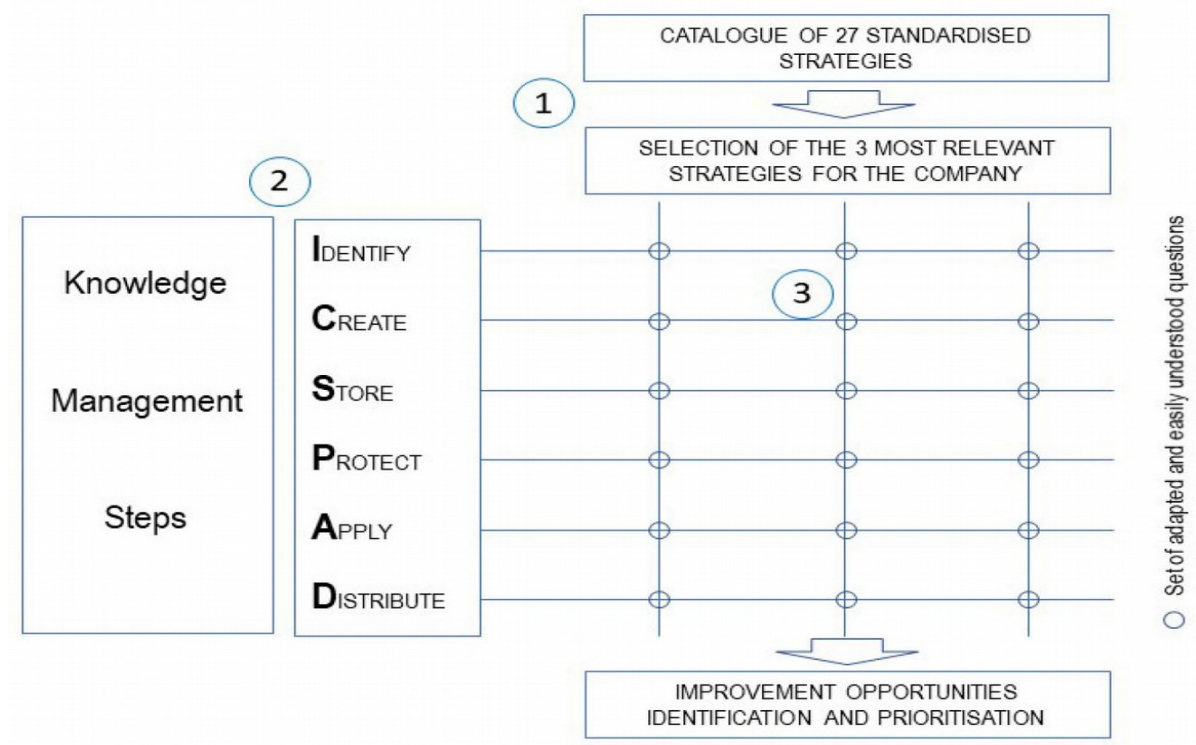

Figure 1. The KM-EZAGUTUZ pillars 
In relation to strategies (the first pillar), the method proposes a catalogue of 27 potential generic strategies grouped into eight categories (innovation, market, efficiency, alliances, people, digitalisation, circular economy and financing) that a company might consider when assessing its KM approach. These strategies were detailed based on various studies on strategies in SMEs (Leitner \& Güldenberg, 2010).

The set of general strategies proposed for SMEs is represented in the table below (Table 1).

\begin{tabular}{|c|c|c|}
\hline $\begin{array}{l}\text { Strategy } \\
\text { Category }\end{array}$ & Strategy & Description \\
\hline \multirow{5}{*}{ Innovation } & $\begin{array}{l}\text { Business model innovation - } \\
\text { value proposition - } \\
\text { diversification }\end{array}$ & $\begin{array}{l}\text { Strategy focused on the innovation of what the company develops and sells } \\
\text { to its customers, to whom it sells or how it sells it and the mechanisms of } \\
\text { income generation. }\end{array}$ \\
\hline & Product innovation & $\begin{array}{l}\text { Strategy aimed at creating or improving products or services through } \\
\text { technology. }\end{array}$ \\
\hline & Process innovation & Strategy aimed at creating or improving processes through technology. \\
\hline & Servitization & Sales-oriented strategy for product-based services. \\
\hline & Data driven business & $\begin{array}{l}\text { These are all the strategies and technologies used by companies for data } \\
\text { analysis and information management. }\end{array}$ \\
\hline \multirow{4}{*}{ Market } & $\begin{array}{l}\text { Diversification of the client } \\
\text { portfolio }\end{array}$ & $\begin{array}{l}\text { Strategy focused on expanding the company's client portfolio. The larger a } \\
\text { company's customer portfolio, the lower the risk of business deterioration. }\end{array}$ \\
\hline & Marketing & $\begin{array}{l}\text { Strategy aimed at attracting and retaining customers, seeking two-way } \\
\text { communication between the company and the customer. }\end{array}$ \\
\hline & Personalisation & $\begin{array}{l}\text { Customer-oriented strategy, linked to the expectations and needs that } \\
\text { customers have with respect to the brand. }\end{array}$ \\
\hline & Internationalisation & $\begin{array}{l}\text { Strategy focused on competing in new economic, political, social and cultural } \\
\text { contexts based on the search for markets in other countries. }\end{array}$ \\
\hline \multirow{6}{*}{ Efficiency } & Advanced management & $\begin{array}{l}\text { Strategy focused on the application of management models and tools that } \\
\text { improve the organisation's capacity, innovation and competitiveness, as well } \\
\text { as the adaptation of the capacities and skills of the management team to } \\
\text { improve business management. }\end{array}$ \\
\hline & Productivity & $\begin{array}{l}\text { Strategy focused on improving the efficiency indicator that relates the } \\
\text { amount of resources used to the amount of production obtained. Strategy } \\
\text { that promotes an efficient productive system, personnel and processes. }\end{array}$ \\
\hline & Quality improvement & $\begin{array}{l}\text { Strategy of continuous improvement, centred on improving the quality of } \\
\text { products and processes through the adaptation of the products to the needs of } \\
\text { the clients (product quality) and the improvement of the processes through the } \\
\text { control of the process variables to achieve zero defects (process quality). }\end{array}$ \\
\hline & Improving logistics & $\begin{array}{l}\text { A strategy focused on the efficient management of the value chain that seeks } \\
\text { the efficient planning, implementation and control of the flow of raw } \\
\text { materials, in-process inventory, finished products and related information } \\
\text { from the place/country of origin to the place/country of destination in the } \\
\text { most efficient and economical way to achieve customer satisfaction. }\end{array}$ \\
\hline & Supplier development & $\begin{array}{l}\text { Strategy focused on the development of high value-added relationships } \\
\text { between customers and suppliers. The aim is to have specialised, competitive } \\
\text { products and suppliers aligned with the company's strategic plans, thus } \\
\text { achieving a well-integrated supply chain ready to attract new projects. }\end{array}$ \\
\hline & Safety in the workplace & $\begin{array}{l}\text { Strategy focused on the development of a safe and healthy working } \\
\text { environment. Centred on a culture of prevention of occupational risks that } \\
\text { translates into safe and healthy behaviour at work, and the continuous } \\
\text { improvement of working conditions and quality of life of the working } \\
\text { group, here responding to the new challenges related to emerging risks and } \\
\text { adapting work to the changing characteristics and capacities of people. }\end{array}$ \\
\hline
\end{tabular}




\begin{tabular}{|c|c|c|}
\hline $\begin{array}{l}\text { Strategy } \\
\text { Category }\end{array}$ & Strategy & Description \\
\hline \multirow{3}{*}{ Alliances } & Collaboration networks & $\begin{array}{l}\text { The SME, aware of the difficulties of competing in global markets on an } \\
\text { individual basis, plans to identify potential partners and assess their suitability } \\
\text { to establish synergetic relationships after a selection process to improve their } \\
\text { competitive position. }\end{array}$ \\
\hline & Strategic alliances & $\begin{array}{l}\text { Once the company has defined its strategy, it identifies the partners that can } \\
\text { best support this strategy and starts a process of selection, contact and } \\
\text { agreements that allow it to leverage its positions on the strategic plan route. }\end{array}$ \\
\hline & Technological alliances & $\begin{array}{l}\text { A particular case related to the above one in which the company relies on } \\
\text { external entities to innovate in product, process or management. To do this, } \\
\text { the company must have an innovation strategy and identify potential } \\
\text { partners, for which it will have to establish a process for using internal and } \\
\text { external knowledge. }\end{array}$ \\
\hline \multirow{5}{*}{ People } & Attracting talent & $\begin{array}{l}\text { Strategy oriented towards the detection of key positions for the organisation } \\
\text { and focus of all its efforts on locating in them those workers with the best } \\
\text { competences and an outstanding performance record. }\end{array}$ \\
\hline & Training & $\begin{array}{l}\text { Strategy oriented to the diagnosis of needs and training strategies within the } \\
\text { organisation. Growing competition in the labour market has led companies } \\
\text { to a constant need for renewal, as well as an improvement in their products } \\
\text { and services. }\end{array}$ \\
\hline & Employee participation & $\begin{array}{l}\text { Strategy oriented towards promoting workers as owners of the organisations } \\
\text { in which they carry out their work activities. Workers own the means of } \\
\text { production, participate in management and control economic decisions. }\end{array}$ \\
\hline & Generational change & $\begin{array}{l}\text { Strategy oriented towards the acquisition of knowledge and skills necessary } \\
\text { for the correct management of an organisation by successors. }\end{array}$ \\
\hline & People management & $\begin{array}{l}\text { People-oriented and people-based strategy. Refers to all the policies, practices } \\
\text { and systems that influence the attitudes, behaviours and performance of the } \\
\text { people who make up the organisation. }\end{array}$ \\
\hline \multirow{2}{*}{ Digitalisation } & Industry 4.0 & $\begin{array}{l}\text { The company knows the basic concept of Industry } 4.0 \text {, as well as the } \\
\text { associated technologies and their applicability in the company. It has used the } \\
\text { existing knowledge in the company and externally and has established the } \\
\text { necessary knowledge to implement a strategy based on Industry 4.0. In } \\
\text { addition, the company has identified the knowledge needed and has } \\
\text { established a strategy to acquire it. }\end{array}$ \\
\hline & Digital transformation & $\begin{array}{l}\text { The company is aware of the concept of digital transformation of its } \\
\text { processes, as well as the associated technologies and applicability in its } \\
\text { company. To do so, it has used the existing knowledge in the company and } \\
\text { externally, establishing the necessary knowledge to implement a strategy } \\
\text { based on digitalisation. Furthermore, it has identified the knowledge it needs } \\
\text { and has established a strategy to acquire it. }\end{array}$ \\
\hline $\begin{array}{l}\text { Circular } \\
\text { economy }\end{array}$ & Circular economy & $\begin{array}{l}\text { Strategy focused on a system of resource use where the reduction, reuse and } \\
\text { recycling of elements is a priority. }\end{array}$ \\
\hline Financing & Financing model & $\begin{array}{l}\text { Strategy focused on obtaining funds for the start-up, maintenance or } \\
\text { expansion of a company or project. It consists of acquiring the money the } \\
\text { company needs to make investments and carry out its operations. }\end{array}$ \\
\hline
\end{tabular}

Table 1. Catalogue of strategies

The second pillar is based on the ICSPAD cycle. The KM cycle was based on different reviews regarding KM processes (Fink \& Ploder, 2009; Wee \& Chua, 2013), and it involves six steps: (1) identifying key knowledge, (2) creating knowledge within the organisation, (3) storing knowledge in an appropriate way, (4) protecting knowledge, (5) applying knowledge and (6) distributing knowledge. 
Regarding the third pillar (Figure 1), for each strategy and each phase of the KM cycle (ICSPAD), a series of specific questions adapted for each strategy and step, here configured as a maturity model (Kuriakose et al., 2010), were developed to help companies assess the KM approach of the organisation and identify potential action plans in an intuitive way.

As an example, the table below presents the series of questions for one of the 27 selected strategies. In particular, the questions relating to a strategy based on marketing are presented (Table 3).

To make the process and testing of the proposed method operational, a tool was generated for the collection and agile processing of the data (based on a spreadsheet) that also allowed for the generation of the final report for the company.

\begin{tabular}{c|l|} 
Phase & \multicolumn{1}{|c}{ ICSPAD description } \\
\hline I & How the knowledge needed to implement the strategy is identified. \\
\hline C & How the processes for generating the knowledge needed for the strategy and the resources for it are configured. \\
\hline S & How the information is stored and made as explicit as possible. \\
\hline P & How the knowledge linked to this strategy is protected. \\
\hline A & How the knowledge is used to make decisions regarding the strategy. \\
\hline D & How knowledge is distributed among the key people and stakeholders in the development of the strategy. \\
\hline
\end{tabular}

Table 2. ICSPAD Cycle

\begin{tabular}{|c|l|}
\hline ICSPAD & \multicolumn{1}{|c|}{ QUESTIONS } \\
\hline I & $\begin{array}{l}\text { What are the marketing techniques to reach your customers? What about loyalty programmes? Do you know } \\
\text { what the four Ps of the company are? What is the current market position of the company? }\end{array}$ \\
\hline C & $\begin{array}{l}\text { Do you have processes or people assigned to apply the different marketing techniques? Are there people } \\
\text { dedicated to the analysis of the best companies? Do you use any process to analyse the positioning of the } \\
\text { company? }\end{array}$ \\
\hline S & $\begin{array}{l}\text { Do you adequately store the information related to the four Ps? Have the different marketing techniques been } \\
\text { adequately explained? Do you explicitly store the knowledge about the company's positioning? }\end{array}$ \\
\hline P & $\begin{array}{l}\text { Have you taken measures to protect the knowledge linked to marketing techniques? Is the knowledge about the } \\
\text { four Ps of the company adequately protected? Have you taken the necessary measures to protect excellence in } \\
\text { customer service? }\end{array}$ \\
\hline A & $\begin{array}{l}\text { Do you use the knowledge related to the positioning of the company for decision making? Do you manage } \\
\text { strategic projects based on the knowledge related to the four Ps? Do you take into account the knowledge } \\
\text { about the best companies when defining strategic business processes? }\end{array}$ \\
\hline D & $\begin{array}{l}\text { Do you distribute knowledge related to the positioning of the company among key people and stakeholders? Is } \\
\text { the knowledge related to marketing techniques shared with key people and stakeholders in the development of } \\
\text { the strategy? Do you distribute the knowledge related to customer loyalty with the key people and stakeholders } \\
\text { in the development of the strategy? }\end{array}$ \\
\hline
\end{tabular}

Table 3. Set of questions for a marketing strategy-based KM

\section{KM-EZAGUTUZ Method Process}

In this section, the process of evaluation and prioritisation of the improvement opportunities proposed in the KM-Ezagutuz method is presented. This process is presented graphically in the following figure (Figure 2).

Initially, a KM evaluation team is set up in the company. This team is composed of less than six people. It is advisable that they have a global vision of the company while also covering a wide part of the company's activities. Hence, the involvement of the management team is desirable. 


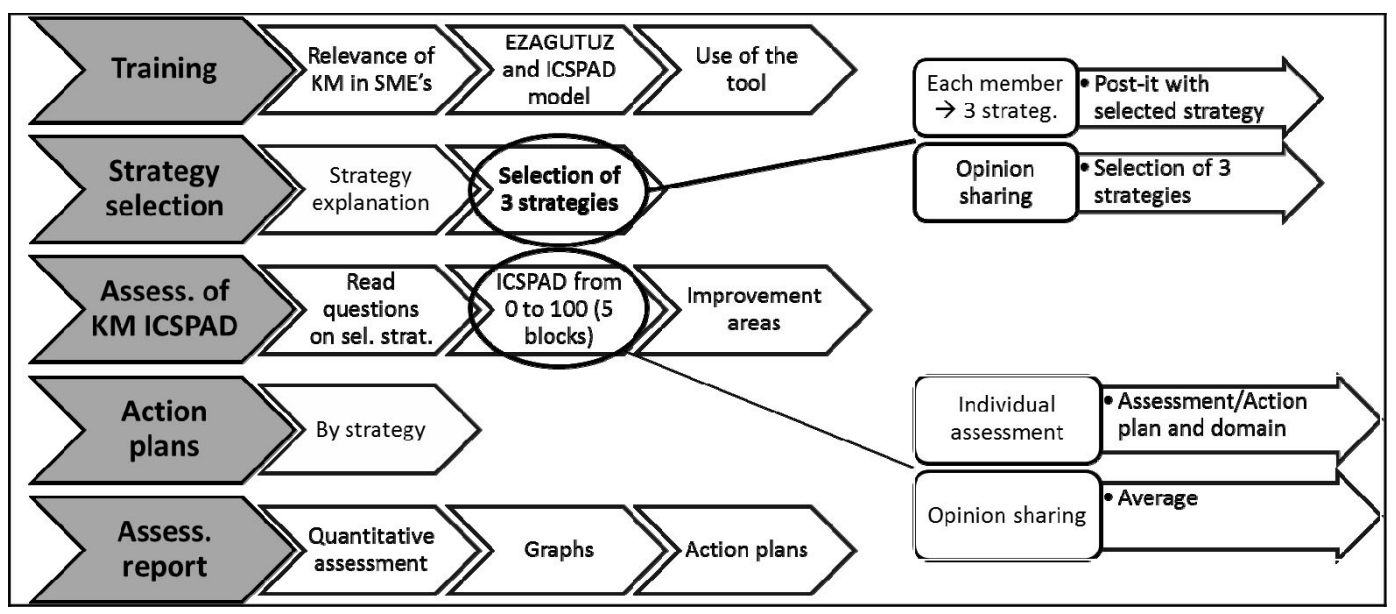

Figure 2. The KM-EZAGUTUZ method

The process starts with brief training on the importance of knowledge management in SMEs, the KM-EZAGUTUZ evaluation process and an explanation of the use of the tool generated for this process.

Then, the most suitable strategies for the company are selected. To do so, the basic strategies are briefly explained, and each person, based on personal reflection, selects the three strategies that they consider best adapted to the company's context. The team then agrees on the three most relevant strategies on which the evaluation will be carried out.

Then, based on the ICSPAD questions, for each of the three selected strategies, each person makes a quantitative assessment of the company's degree of maturity and an identification of the possible improvement opportunities for the company to strengthen those aspects in which the company is strong or correct those for which is weak. The assessments are then shared with the team, and the quantitative evaluation is agreed upon; the potential improvements for the organisation are then selected.

Once the process has been completed, action plans are selected to devise strategies that take into account the availability of resources within the organisation. A report is then produced that captures the essential elements of the information generated during the assessment process.

The entire process is scheduled to last six hours and includes an initial presentation of the company's management to discuss the company's interest in addressing the assessment process.

\section{Contrast of the KM-EZAGUTUZ}

During the current research, prior to the field study, the method was explored through a focus group composed of regional development centres, new company promotion agencies and industry representatives. The focus group involved a day to reflect, discuss and draw conclusions in relation to what was identified in the initial design process of the proposed process. This discussion with experts sought to investigate the important aspects, attitudes and elements discovered in previous analyses in relation to KM. As a result, changes were incorporated into the method.

Once the modifications proposed by the focus group were incorporated, a field test was carried out in five companies to test the proposed method. The size of four out of the five companies ranged between 5 and 23 employees; the exception was a company of 200 employees. This company was used to explore the method in larger companies. The companies in which the comparison was made belonged to diverse sectors, such as the manufacturing of mechatronic tools, component machining, service companies, tension spring manufacturing and social health services.

Being aware of the difficulties regarding resources and time availability that exist in SMEs and micro-enterprises, this process was carried out in four to five hours in a single meeting. During the process of applying the method, it 
was found that the availability of time in small or very small organisations represented a handicap for the application of such methodologies.

As a culmination of the KM-EZAGUTUZ process, the companies obtained the following deliverables: 1) a selection of key strategies for the company that were explicitly established and that helped the companies assess the degree of alignment and coherence between the different team members; 2) a maturity profile of the company's KM approach for each of the strategies selected in accordance with the ICSPAD assessment cycle (see the example in Figure 3); 3) an identification of potential action plans to improve the company's KM; and 4) a prioritisation of these action plans according to their impact on the company's results.

One of the more important outcomes of the validation dealt with the generation of value added to companies. Therefore, the companies were asked to evaluate different elements regarding the method: usefulness, need for external support, value versus time spent and interest in repeating the analysis. In addition, the participating companies obtained a report of the selected strategies, with the evaluation of each of them coming from a KM point of view that included the associated degree of maturity and several prioritised potential action plans.

\begin{tabular}{|c|c|c|c|c|c|c|}
\hline & ICSPAD phase questions & $\begin{array}{c}\text { Part. } \\
1\end{array}$ & $\begin{array}{c}\text { Part. } \\
2\end{array}$ & $\begin{array}{c}\text { Part. } \\
3\end{array}$ & $\begin{array}{c}\text { Part. } \\
4\end{array}$ & Average \\
\hline I & $\begin{array}{l}\text { Has the company identfied in an explicit way the fields where Industry } 4.0 \text { can be useful? } \\
\text { Has the company identfied the organisations that could support the implementation of } \\
\text { Industry } 4.0 \text { in those fields? Does the company have information about public programmes } \\
\text { to support Industry } 4.0 \text { implementation? Does the company have an Industry } 4.0 \text { plan } \\
\text { gathering all this information? }\end{array}$ & 80 & 75 & 60 & 75 & 73 \\
\hline C & $\begin{array}{l}\text { Who is responsible in yourf firm for gathering this information? Does the company have } \\
\text { processes intending to gather and analyse the information related to Industry } 4.0 \text { ? Are } \\
\text { there programmed meetings to treat the company's adaptation to Industry } 4.0 \text { ? }\end{array}$ & 80 & 90 & 85 & 85 & 85 \\
\hline S & $\begin{array}{l}\text { Who stores the information about Industry } 4.0 \text { and its adaptation to the firm? Is the } \\
\text { information kept together or split in the organisation? Is the information well structured in a } \\
\text { way that can be accessed easily? }\end{array}$ & 15 & 10 & 5 & 15 & 11 \\
\hline $\mathrm{P}$ & $\begin{array}{l}\text { Taking into account the strategic character ofthe information, is it sufficiently protected? } \\
\text { Are the modfications registered? Are the access points to the information recorded? }\end{array}$ & 10 & 20 & 15 & 20 & 16 \\
\hline$A$ & $\begin{array}{l}\text { When making strategic decisions, is the information about Industry } 4.0 \text { opportunities used } \\
\text { in a proper manner? Is the Industry } 4.0 \text { analysis integrated in the strategic plan elaboration } \\
\text { process? Is Industry } 4.0 \text { application part of the CEO's agenda? }\end{array}$ & 80 & 75 & 75 & 70 & 75 \\
\hline$D$ & $\begin{array}{l}\text { Do the people who need this information have access to the updated data? Are there } \\
\text { specific meetings for providing Industry } 4.0 \text { information? Is the application of Industry } 4.0 \text { in } \\
\text { the firm specifically and explicitly part of people's agendas? }\end{array}$ & 10 & 15 & 10 & 15 & 13 \\
\hline
\end{tabular}

Figure 3. Example of a KM assessment for an Industry 4.0 strategy

\section{Real Case Tests}

In this section, we present the results obtained from the fieldwork carried out in five real pilot tests. Each of the pilot tests resulted in a report setting out the process, as well as the outcome of each of the phases. This report was given to the company at the end of the session.

The table below (Table 4) presents each company's general observations of the evaluation process, reflections of $\mathrm{KM}$ in their company and contributions to its improvement.

In addition, the fieldwork helped identify some key challenges in relation to KM and other issues concerning the method and tool developed, such as the following:

- The companies emphasised the importance of KM for the development of their activities, processes and projects and the fact that most of their knowledge belongs to certain people, limiting the autonomy of other people in the company. 
- They declared that knowledge in SMEs is key to addressing customer needs. They considered that the protection of knowhow, as well as the need to make it explicit and standardised, are also crucial.

- They considered that the key barriers to KM in their companies are related to the efforts needed in data processing, legal aspects, lack of time to meet and lack of standardised processes.

- Companies also stress the need for 'simple' and 'pragmatic' tools to manage and implement their KM approach.

- The participating companies mainly chose strategies regarding diversification of the customer portfolio and product or process innovation to evaluate their $\mathrm{KM}$ approach. In addition, some companies also chose financing, marketing, training or digital transformation.

The concrete result of the process for the companies was highly valued, especially in those companies where the method could be developed in all its stages.

Finally, regarding the KM assessment approach, as well as the method and tools developed, the companies highlighted two main advantages: (1) The method helps to assess $\mathrm{KM}$ in companies based on activities that are intuitive and in line with the chosen strategies. (2) The method promotes a common understanding of strategies in the company, a shared assessment among team members and a focused approach towards KM.

\begin{tabular}{|c|c|c|}
\hline N. & Size & Comments \\
\hline$\# 1$ & 200 & $\begin{array}{l}\text { The overall process is not intuitive. It requires external support. The process helps verify the alignment of } \\
\text { the strategic vision in the group of people. Day-to-day life makes it difficult to deal with these kinds of } \\
\text { processes. KM requires a cultural shift towards a culture of knowledge sharing. The process has been } \\
\text { agile. It is proposed to increase the duration and repeat on an annual basis. }\end{array}$ \\
\hline$\# 2$ & 18 & $\begin{array}{l}\text { After the initial presentation meeting about the process, the company struggled to meet because of the } \\
\text { limited time availability of the team members. Therefore, the process could not be completed. }\end{array}$ \\
\hline \#3 & 5 & $\begin{array}{l}\text { The intervention model is useful. There is an internal utility view of the process. The process requires } \\
\text { thinking about the knowledge necessary to project into the market and the future. It is necessary to } \\
\text { formalise knowledge because this allows placing value in what has been done. The strategy 'menu' helps to } \\
\text { make explicit its own strategies. It would be of interest not to focus exclusively on process innovation on } \\
\text { the technological side. This requires external support. Proper time frame: one year. }\end{array}$ \\
\hline$\# 4$ & 5 & $\begin{array}{l}\text { They do not give much importance to protecting knowledge. You learn a lot from the industry from } \\
\text { different perspectives. They consider the process to be agile. External support is required. Detailed } \\
\text { questions help; however, in some cases, they are not easy to understand. Proper time frame: annual. }\end{array}$ \\
\hline$\# 5$ & 23 & $\begin{array}{l}\text { It requires support for the interpretation of concepts and tools. It is emphasised that as a result, there is a } \\
\text { self-diagnosis that the process is agile and helps reflect the key issues of the organisation. A good practice } \\
\text { guide for the various sections of the model would be of interest. Proper time frame: six months. }\end{array}$ \\
\hline
\end{tabular}

Table 4. Fieldwork

\section{Conclusions}

In the current article, we have presented the process followed for the definition, application and evaluation of a method that aids in the strategic assessment, identification and prioritisation of KM initiatives in SMEs. This method, which is focused on the role of $\mathrm{KM}$ as a support to business strategy, embraces both business strategy and $\mathrm{KM}$ process (ICSPAD) approaches by using a catalogue of standard strategies that help companies focus their KM though an assessment based on a specific maturity model.

The conclusions obtained through the action research confirm the validity of the method for SMEs (especially for small and micro-enterprises), as well as for the larger company involved in the testing. The method, which was developed and supported in a prototype tool, helps companies in a short period (four to five hours) determine and prioritise actions for better $\mathrm{KM}$ in accordance with the strategies the company wants to foster, complementing existing toolkits for KM in SMEs (Fink \& Ploder, 2009). 
The companies positively value the explanation of the strategies they can develop, as well as the contrast between the different people and their understanding and alignment of these strategies within the company. Indeed, the importance of the relationship between strategy and communication is clearly proposed by (Alberto-Pérez, 2014).

Moreover, the possibility of having a set of questions on KM adapted to each strategy helps develop a more natural and less abstract reflection, allowing for an easier application of the method.

Furthermore, the people in the company who have participated in the project state that the method generates organisational learning based on the different internal perspectives of the company, underlining the synergies between KM and learning organisations as suggested by some studies (Loermans, 2002). The participants also consider that the relationship between the benefit obtained and the time dedicated is positively value aligned with other studies and that an annual periodicity may be appropriate for this method.

As an aspect to be improved regarding the method, it would be necessary to refine the texts of the explanatory guide, the ease of use of the instrument and make an approach that allows for more autonomous use of the method by enterprises. However, external support has always been appreciated for the clarification of the elements of the guide and the terms of the evaluation or for ideas that are 'outside the box'.

As explained in the current article, one of the companies was unable to complete the process because of difficulties in finding the time to meet. The lack of time for people to meet and share diagnoses and reflections is, in many cases, a circumstance that questions the real capacity of many companies to develop projects and KM initiatives, a notion that is in accordance with some research conclusions (Cerchione, Esposito \& Spadaro, 2015; Hutchinson \& Quintas, 2008).

Regarding the conclusions on KM in SMEs, the companies emphasise the importance of the knowledge of employees as a key to the development of the activities, processes and projects of the company. They also mention that the fact that knowledge is concentrated in certain people means that in addition to the risk associated with this concentration, the autonomy and capacity for self-management are limited to the rest of the organisation. These comments are aligned with previous studies (Wee \& Chua, 2013) stressing the idea that owners are the sole drivers of KM processes in SMEs.

In addition, $\mathrm{KM}$ is not being prioritised as a key aspect for many companies, to the detriment of more urgent elements. The cross-cutting nature of knowledge management and the difficulties of its operationalisation relegate it to the list of priorities for managers (Edvardsson, 2009).

As observed in the fieldwork, companies have trouble defining how to store and protect their knowhow, as well as the mechanisms and rules related to explaining company knowledge. Companies do not have or do not know about simple, agile and low-cost tools to help them in these tasks, making it difficult to develop specific actions and projects. Furthermore, according to the participating companies, the main barriers to better knowledge management are those related to data processing (clients, people), legal aspects, lack of time for management, lack of standardisation, necessary resources, lack of simple systems and lack of standardised processes.

\section{Acknowledgement}

We are thankful for the participation of the companies in the fieldwork portion in this research.

\section{Declaration of Conflicting Interests}

The authors declared no potential conflicts of interest with respect to the research, authorship, and/or publication of this article.

\section{Funding}

This research has received financial support from the Economic Promotion Department of the Provincial Council of Gipuzkoa. 


\section{References}

Alberto-Pérez, R. (2014). La estrategia como campo de estudio. ¿'Tenemos ya un nuevo paradigma? Revista de Mediterránea de Comunicación, 5(2). https:/ / doi.org/10.14198/medcom2014.5.2.03

Alvarez, I., Cilleruelo, E., \& Zamanillo, I. (2016). Is Formality in Knowledge Management Practices Related to the Size of Organizations? The Basque Case. Human Factors and Ergonomics In Manufacturing. https://doi.org/10.1002/hfm.20618

Cerchione, R., Esposito, E., \& Spadaro, M.R. (2015). The spread of knowledge management in SMEs: A scenario in evolution. Sustainability (Switzerland), 7(8), 10210-10232. https://doi.org/10.3390/su70810210

Cerchione, R., Esposito, E., \& Spadaro, M.R. (2016). A literature review on knowledge management in SMEs. Knowledge Management Research and Practice, 14(2), 169-177. https://doi.org/10.1057/kmrp.2015.12

Chawla, D., \& Joshi, H. (2010). Knowledge management initiatives in Indian public and private sector organizations. Journal of Knowledge Management, 14(6), 811-827. https://doi.org/10.1108/13673271011084871

Civi, E. (2000). Knowledge management as a competitive asset: a review. Marketing Intelligence \&amp; Planning, 18(4), 166-174. https://doi.org/10.1108/02634500010333280

Clarke, T., \& Rollo, C. (2001). Corporate initiatives in knowledge management. Education + Training, 43, $206-214$. https://doi.org/10.1108/00400910110399201

Costa, V., \& Monteiro, S. (2016). Key knowledge management processes for innovation: a systematic literature review. VINE Journal of Information and Knowledge Management Systems, 46(3), 386-410.

https://doi.org/10.1108/VJIKMS-02-2015-0017

Drew, S. (1999). Building knowledge management into strategy: Making sense of a new perspective. Long Range Planning, 32(1), 130-136. https:// doi.org/10.1016/S0024-6301(98)00142-3

Durst, S., \& Edvardsson, I.R. (2012). Knowledge management in SMEs: A literature review. Journal of Knowledge Management, 16(6), 879-903. https://doi.org/10.1108/13673271211276173

Edvardsson, I.R. (2009). Is knowledge management losing ground Developments among Icelandic SMEs. Knowledge Management Research and Practice, 7(1), 91-99. https://doi.org/10.1057/kmrp.2008.30

Fink, K., \& Ploder, C. (2009). Knowledge management toolkit for SMEs. International Journal of Knowledge Management, 5(1), 46-60. https://doi.org/10.4018/jkm.2009010104

Gao, T., Chai, Y., \& Liu, Y. (2017). A review of knowledge management and future research trend. In $A C M$ International Conference Proceeding Series, Part F1306, 82-92. https://doi.org/10.1145/3126973.3126997

Henao-Calad, M., Rivera Montoya, P., \& Uribe Ochoa, B. (2017). Knowledge management processes and intellectual property management processes: An integrated conceptual framework. AD-Minister, 31, 137-160. https://doi.org/10.17230/ad-minister.31.8

Hutchinson, V., \& Quintas, P. (2008). Do SMEs do knowledge management?: Or simply manage what they know? International Small Business Journal, 26(2), 131-154. https:// doi.org/10.1177/0266242607086571

Jackson, B. (2001). Peter Senge and the learning organization. In Management Gurus and Management Fashions. https://doi.org/10.4324/9780203471999.ch6

Kuriakose, K., Satya Murty, S., \& Swaminathan, P. (2010). Knowledge management maturity models - a morphological analysis. Journal of Knowledge Management Practice, 11(3). Available at: http://www.tlainc.com/articl232.htm

Kurniawati, A., Wiratmadja, I.I., Sunaryo, I., \& Ari Samadhi, T.M.A. (2019). Relationship among Knowledge Management, Innovation, and Performance: A Systematic Literature Review. In 2019 IEEE 6th International Conference on Industrial Engineering and Applications, ICIEA 2019 (700-704). https:/ /doi.org/10.1109/IEA.2019.8714825 
Lee, C.S., \& Wong, K.Y. (2015). Development and validation of knowledge management performance measurement constructs for small and medium enterprises. Journal of Knowledge Management. https://doi.org/10.1108/JKM-10-2014-0398

Lee, K.S., Lim, G.H., \& Tan, S.J. (1999). Dealing with Resource Disadvantage: Generic Strategies for SMEs. Small Business Economics, 12(4), 299-311. https://doi.org/10.1023/A:1008085310245

Leitner, K.H., \& Güldenberg, S. (2010). Generic strategies and firm performance in SMEs: A longitudinal study of Austrian SMEs. Small Business Economics, 35(2), 169-189. https://doi.org/10.1007/s11187-009-9239-x

Loermans, J. (2002). Synergizing the learning organization and knowledge management. Journal of Knowledge Management, 6(3), 285-294. https://doi.org/10.1108/13673270210434386

McEvily, S.K., \& Chakravarthy, B. (2002). The persistence of knowledge-based advantage: An empirical test for product performance and technological knowledge. Strategic Management Journal. https://doi.org/10.1002/smj.223

Mohamed, E.E. (2019). Knowledge management: An integrative approach literature review. International Journal of Knowledge Management Studies, 10(2), 175-204. https://doi.org/10.1504/IJKMS.2019.099130

Nonaka, I. (1994). A Dynamic Theory of Organizational Knowledge Creation. Organization Science. https://doi.org/10.1287/orsc.5.1.14

Samiei, E., \& Habibi, J. (2020). The Mutual Relation Between Enterprise Resource Planning and Knowledge Management: A Review. Global Journal of Flexible Systems Management, 21(1), 53-66. https://doi.org/10.1007/s40171-019-00229-2

Wee, J.C.N., \& Chua, A.Y.K. (2013). The peculiarities of knowledge management processes in SMEs: The case of Singapore. Journal of Knowledge Management, 17(6), 958-972. https://doi.org/10.1108/JKM-04-2013-0163

White, R.E. (1986). Generic business strategies, organizational context and performance: An empirical investigation. Strategic Management Journal, 7(3), 217-231. https://doi.org/10.1002/smj.4250070304

Wiig, K.M. (1997). Knowledge management: Where did it come from and where will it go? Expert Systems with Applications, 13(1), 1-14. https://doi.org/https://doi.org/10.1016/S0957-4174(97)00018-3

Zheng, W., Yang, B., \& McLean, G.N. (2010). Linking organizational culture, structure, strategy, and organizational effectiveness: Mediating role of knowledge management. Journal of Business Research, 63(7), 763-771. https://doi.org/10.1016/j.jbusres.2009.06.005

Journal of Industrial Engineering and Management, 2021 (www.jiem.org)

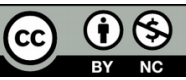

Article's contents are provided on an Attribution-Non Commercial 4.0 Creative commons International License. Readers are allowed to copy, distribute and communicate article's contents, provided the author's and Journal of Industrial Engineering and Management's names are included. It must not be used for commercial purposes. To see the complete license contents, please visit https://creativecommons.org/licenses/by-nc/4.0/. 